\title{
Development and Validation of a Stability-Indicating Liquid Chromatographic Method for the Assay of Cabazitaxel
}

\author{
M. MATHRUSRI ANNAPURNA ${ }^{* 1}$, B. VENKATESH ${ }^{1}$, \\ K. PRAMADVARA ${ }^{1}$ and S. HEMCHAND ${ }^{2}$ \\ ${ }^{1}$ Department of Pharmaceutical Analysis \& Quality Assurance, \\ GITAM Institute of Pharmacy, GITAM University, Visakhapatnam, India \\ ${ }^{2}$ Inogent Laboratories Pvt. Ltd., Hyderabad, India \\ mathrusri2000@yahoo.com
}

Received 31 January 2014 / Accepted 19 February 2014

\begin{abstract}
A validated stability-indicating high-performance liquid chromatographic technique was developed for the determination of cabazitaxel. Chromatographic separation was performed on Shimadzu Model CBM-20A/20 Alite, using a mixture of sodium acetate buffer ( $\mathrm{pH} 4.0)$ and acetonitrile $(30: 70, \mathrm{v} / \mathrm{v})$ as mobile phase with a flow rate of $1.0 \mathrm{~mL} / \mathrm{min}$. Cabazitaxel was subjected to stress conditions (acidic, alkaline, oxidation photolytic and thermal degradations and the method was validated as per ICH guidelines.
\end{abstract}

Keywords: Cabazitaxel, RP-HPLC, Stability-indicating, ICH

\section{Introduction}

Cabazitaxel is a semi-synthetic derivative of a natural taxoid ${ }^{1}$ used for the treatment of hormone-refractory prostate cancer. Unlike other taxane compounds, this agent is a poor substrate for the membrane-associated, multidrug resistance (MDR), $P$-glycoprotein (P-gp) efflux pump and may be useful for treating multidrug-resistant tumors. It is a microtubule inhibitor and the fourth taxane to be approved as a cancer therapy. Cabazitaxel has been approved in the US by the Food and Drug Administration (FDA) in June $2010^{2}$ and in Europe by the European Medicines Agency (EMA) in January 2011 in combination with prednisone for the treatment of patients with castration resistant metastatic prostate cancer whose disease progresses after docetaxel treatment ${ }^{3}$, based on the results of the TROPIC trail investigating cabazitaxel plus prednisone versus mitoxantrone plus prednisone following docetaxel failure ${ }^{4}$. Cabazitaxel chemically known as $(2 \mathrm{aR}, 4 \mathrm{~S}, 4 \mathrm{aS}, 6 \mathrm{R}, 9 \mathrm{~S}, 11 \mathrm{~S}$, 12S, 12aR, 12bS)-12b-acetoxy-9-(((2R,3S)-3-((tert-butoxycarbonyl)amino)-2-hydroxy-3phenyl propanoyl)oxy)-11-hydroxy-4, 6-dimethoxy-4a, 8, 13, 13-tetramethyl-5-oxo-2a, 3, 4, $4 \mathrm{a}, 5,6,9,10,11,12,12 \mathrm{a}, 12 \mathrm{~b}$-dodecahydro- $1 \mathrm{H}-7,11$-methanocyclodeca ${ }^{5-6}$ benzo $[1,2-\mathrm{b}]$ oxet-12-yl benzoate is chemotherapy drug with molecular formula $\mathrm{C}_{45} \mathrm{H}_{57} \mathrm{NO}_{14}$ and molecular weight $835.93 \mathrm{~g} / \mathrm{mol}$ (Figure 1). Cabazitaxel binds to and stabilizes tubulin, resulting in the inhibition of microtubule depolymerization and cell division, cell cycle arrest 
in the G2/M phase and the inhibition of tumor cell proliferation. Cabazitaxel penetrates the blood-brain barrier. Cabazitaxel is currently being investigated in the setting of metastatic breast cancer progressing after taxane or anthracycline based chemotherapeutic regimens ${ }^{7-8}$.

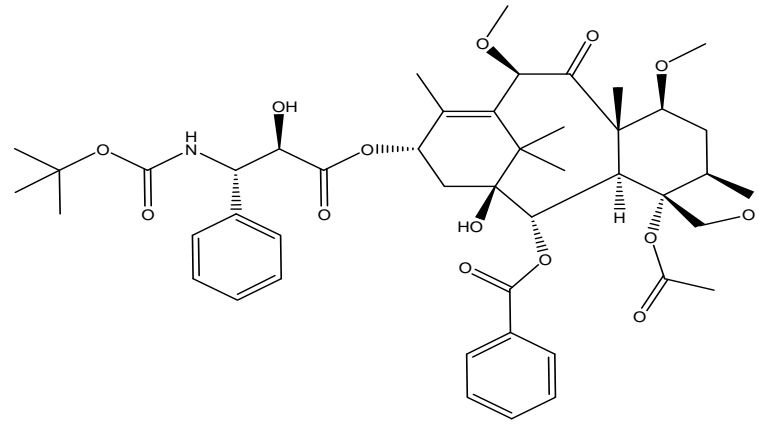

Figure 1. Chemical structure of Cabazitaxel

Very few analytical methods have been reported for the determination of cabazitaxel such as spectroscopic techniques ${ }^{9}$, HPLC $^{10}$, LC-MS/MS in dry blood spots and human plasma $^{11-13}$. As per the literature available till date there was no RP-HPLC method reported. So, at present the authors have developed a stability indicating RP-HPLC method for the determination of cabazitaxel in presence of its degradation products.

\section{Experimental}

Cabazitaxel standard was obtained from Reddy's Labs (India). Acetonitrile (HPLC grade), Sodium hydroxide $(\mathrm{NaOH})$ and Hydrochloric acid $(\mathrm{HCl})$, Glacial acetic acid and Hydrogen peroxide $\left(\mathrm{H}_{2} \mathrm{O}_{2}\right)$ were purchased from Merck (India).

Cabazitaxel is available as infusion with brand name Jevtana ${ }^{\circledR}$ (Sanofi-Aventis, Malaysia) with label claim of $60 \mathrm{mg}$ of drug. All chemicals were of analytical grade and used as received.

\section{Instrumentation}

Chromatographic separation was achieved by using Zorbax SB-C18 column $(150 \mathrm{~mm} \times 4.6 \mathrm{~mm}$ i.d., $3.5 \mu \mathrm{m}$ particle size) for HPLC system of Shimadzu Model CBM-20A/20 Alite, equipped with SPD M20A prominence photodiode array detector, maintained at $25^{\circ} \mathrm{C}$.

\section{Chromatographic conditions}

Isocratic elution was performed using sodium acetate buffer: acetonitrile $(30: 70, \mathrm{v} / \mathrm{v})$ as mobile phase. The overall run time was $10 \mathrm{~min}$. with flow rate $1.0 \mathrm{~mL} / \mathrm{min}$ with UV detection at $210 \mathrm{~nm} .20 \mu \mathrm{L}$ of sample was injected into the HPLC system.

\section{Preparation of stock solution}

Cabazitaxel stock solution $(1000 \mu \mathrm{g} / \mathrm{mL})$ was prepared by weighing accurately $25 \mathrm{mg}$ of Cabazitaxel in a $25 \mathrm{~mL}$ volumetric flask with mobile phase. Working standard solutions were prepared on daily basis from the stock solution with mobile phase and filtered through $0.45 \mu \mathrm{m}$ membrane filter prior to injection.

\section{Preparation of sodium acetate buffer solution ( $\mathrm{pH} 4.0$ )}

The buffer solution ( $\mathrm{pH}-4.0)$ was prepared by mixing $28.6 \mathrm{~mL}$ of glacial acetic acid with $10 \mathrm{~mL}$ of $50 \%(\mathrm{w} / \mathrm{v}) \mathrm{NaOH}$ in a $1000 \mathrm{~mL}$ volumetric flask, dissolving and diluting to volume with HPLC grade water. 


\section{Method validation}

The method was validated for system suitability, linearity, limit of quantitation (LOQ), limit of detection (LOD), precision, accuracy, selectivity and robustness ${ }^{14}$. Linearity test solutions for the assay method were prepared from a stock solution at different concentration levels $(0.1-250 \mu \mathrm{g} / \mathrm{mL})$ of the assay analyte concentration and $20 \mu \mathrm{L}$ of each solution was injected in to the HPLC system and the peak area of the chromatogram obtained was noted. The calibration curve was plotted by taking the concentration on the $\mathrm{x}$-axis and the corresponding peak area on the y-axis. The data was treated with linear regression analysis method.

The limit of quantification and limit of detection were based on the standard deviation of the response and the slope of the constructed calibration curve $(n=3)$, as described in ICH guidelines Q2 $(\mathrm{R} 1)^{15}$.

\section{Precision study}

The intra-day precision of the assay method was evaluated by carrying out 9 independent assays of a test sample of Cabazitaxel at three concentration levels $(20,50$ and $100 \mu \mathrm{g} / \mathrm{mL})$ against a qualified reference standard. The \%RSD of three obtained assay values at three different concentration levels was calculated. The inter-day precision study was performed on three different days i.e. day 1, day 2 and day 3 at three different concentration levels $(20,50$ and $100 \mu \mathrm{g} / \mathrm{mL})$ and each value is the average of three determinations. The $\%$ RSD of three obtained assay values on three different days was calculated.

The accuracy of the assay method was evaluated in triplicate at three concentration levels $(50,100$ and $150 \%)$ and the percentage recoveries were calculated. Standard addition and recovery experiments were conducted to determine the accuracy of the method for the quantification of Cabazitaxel in the drug product. The study was carried out in triplicate at 150,200 and $250 \mu \mathrm{g} / \mathrm{mL}$. The percentage recovery in each case was calculated.

The robustness of the assay method was established by introducing small changes in the HPLC conditions which included wavelength $(232$ and $236 \mathrm{~nm})$, percentage of acetonitrile in the mobile phase (68 and $72 \%)$ and flow rate $(0.9$ and $1.1 \mathrm{~mL} / \mathrm{min})$. Robustness of the method was studied using six replicates at a concentration level of $100 \mu \mathrm{g} / \mathrm{mL}$ of cabazitaxel.

As the marketed formulation was not available the drug was mixed with different excipients available in the laboratory and then extracted using the mobile phase and the percentage recovery was calculated from the calibration curve.

\section{Forced degradation studies}

Forced degradation studies were performed to evaluate the stability indicating properties and specificity of the method ${ }^{10}$. All solutions for stress studies were prepared at an initial concentration of $1 \mathrm{mg} / \mathrm{mL}$ of Cabazitaxel and refluxed for $30 \mathrm{~min}$ at $60{ }^{\circ} \mathrm{C}$ and then diluted with mobile phase. $1.0 \mathrm{mg} / \mathrm{mL}$ Cabazitaxel solution was exposed to acidic degradation with $0.1 \mathrm{M} \mathrm{HCl}$ for $20 \mathrm{~min}$ at $60{ }^{\circ} \mathrm{C}$ the stressed sample was cooled, neutralized and diluted with mobile phase. Similarly stress studies were conducted in alkaline conditions with $0.01 \mathrm{M}$ $\mathrm{NaOH}$ at $60{ }^{\circ} \mathrm{C}$ for $20 \mathrm{~min}$ and neutralized after cooling with proper dilution with mobile phase. Oxidative stress studies were performed using $30 \% \mathrm{H}_{2} \mathrm{O}_{2}$ and thermal stress studies were conducted in thermostat at $60{ }^{\circ} \mathrm{C}$ for $20 \mathrm{~min} .20 \mu \mathrm{L}$ solution of each of these solutions which were exposed to forced degradation studies were injected in to the HPLC system and the chromatograms were recorded from which the percentage recovery as well as the degradants were studied. 


\section{Results and Discussion}

\section{Method optimization}

The performance characteristics of the present stability indicating liquid chromatographic method was compared and discussed in detail with the previously published methods in Table 1. Initially the stressed samples were analyzed using a mixture of sodium acetate buffer ( $\mathrm{pH} 4.0)$ : acetonitrile (50:50, v/v) with a flow rate of $0.8 \mathrm{~mL} / \mathrm{min}$ in which the peak symmetry was not satisfactory. The flow rate was changed to $1.0 \mathrm{~mL} / \mathrm{min}$ and again the drug sample was injected in to the loop where a sharp peak was eluted with tailing. Finally the mobile phase composition was modified as sodium acetate buffer $(\mathrm{pH} 4.0)$ : acetonitrile $(30: 70, \mathrm{v} / \mathrm{v})$ and a sharp peak were eluted at retention time $3.823 \pm 0.03 \mathrm{~min}$. (UV detection at $210 \mathrm{~nm}$ ) which was chosen as the best chromatographic response for the entire study.

\section{Method validation}

Cabazitaxel shows linearity over a concentration range of $0.1-250 \mu \mathrm{g} / \mathrm{mL}$ (Table 2) with \% RSD $0.14-0.51$. The linear regression equation was found to be $y=26523 x+971.45\left(r^{2}=0.9993\right)$. The LOQ was found to be $0.0738 \mu \mathrm{g} / \mathrm{mL}$ and the LOD was found to be $0.0244 \mu \mathrm{g} / \mathrm{mL}$.

Table 1. Comparison of the previously published liquid chromatographic methods with the present method

\begin{tabular}{|c|c|c|c|c|c|}
\hline S. No. & Method/Reagent & $\lambda \mathrm{nm}$ & Linearity $\mu \mathrm{g} / \mathrm{mL}$ & Remarks & Ref. \\
\hline 1. & $\begin{array}{l}\text { Phosphate buffer: } \\
\text { Acetonitrile }(30: 70, \mathrm{v} / \mathrm{v})\end{array}$ & 230 & $0.1-150$ & $\begin{array}{l}\text { Stability } \\
\text { indicating method }\end{array}$ & {$[10]$} \\
\hline 2. & $\begin{array}{l}10 \mathrm{mM} \text { ammonium } \\
\text { hydroxide and methanol } \\
(83: 17, \mathrm{v} / \mathrm{v})(\mathrm{pH}=3 \pm 0.1)\end{array}$ & 275 & $2-20$ & $\begin{array}{l}\text { Very narrow } \\
\text { linearity range }\end{array}$ & {$[11]$} \\
\hline 3. & $\begin{array}{l}\text { Acetonitrile: ammonium } \\
\text { acetate }(20 \mathrm{mM})(80: 20, \mathrm{v} / \mathrm{v})\end{array}$ & 236 & $2.49-99.60$ & $\begin{array}{l}\text { Very narrow } \\
\text { linearity range }\end{array}$ & {$[12]$} \\
\hline 4. & $\begin{array}{l}\text { Phosphate buffer: } \\
\text { Acetonitrile: Methanol } \\
(40: 40: 20, \mathrm{v} / \mathrm{v})\end{array}$ & 362 & $(10-100) 10^{3}$ & $\begin{array}{l}\text { Mixture of } \\
\text { solvents }\end{array}$ & [13] \\
\hline 5. & $\begin{array}{l}\text { Tetra butyl ammonium } \\
\text { hydrogen sulphate : } \\
\text { Methanol }(20: 80, \mathrm{v} / \mathrm{v})\end{array}$ & 210 & $0.1-250$ & $\begin{array}{l}\text { Wide linearity } \\
\text { range Stability } \\
\text { indicating method }\end{array}$ & $\begin{array}{l}\text { Present } \\
\text { work }\end{array}$ \\
\hline
\end{tabular}

The \% RSD range was obtained as $0.10-0.26$ and $0.55-0.68$ for intra-day and inter-day precision studies respectively and $99.55-99.94 \%$ of recovery was observed in the accuracy studies with \% RSD 0. 12-0.64 (<2.0\%) (Table 3) indicating that the method is precise and accurate.

Table 2. Linearity of Cabazitaxel

\begin{tabular}{lll}
\hline Conc. $\mu \mathrm{g} / \mathrm{mL}$ & $*$ Mean peak area $\pm \mathrm{SD}$ & $\mathrm{RSD}, \%$ \\
\hline 0.1 & $2788 \pm 9.03$ & 0.32 \\
1 & $28357 \pm 80.25$ & 0.28 \\
5 & $144728 \pm 719.30$ & 0.50 \\
10 & $283098 \pm 920.07$ & 0.33 \\
20 & $514448 \pm 1409.59$ & 0.27 \\
50 & $1353855 \pm 1922.47$ & 0.14 \\
100 & $2567180 \pm 6417.95$ & 0.25 \\
150 & $4028658 \pm 18934.69$ & 0.47 \\
\hline
\end{tabular}

* Mean of three replicates 
Table 3. Precision and accuracy studies of Cabazitaxel

\begin{tabular}{|c|c|c|c|c|}
\hline \multirow[b]{2}{*}{$\begin{array}{l}\text { Conc. } \\
\mu \mathrm{g} / \mathrm{mL}\end{array}$} & \multicolumn{2}{|r|}{ Intra-day precision } & \multicolumn{2}{|c|}{ Inter-day precision } \\
\hline & \multicolumn{2}{|c|}{$*$ Mean peak area \pm SD $(\%$ RSD $)$} & \multicolumn{2}{|c|}{$\begin{array}{c}* \text { Mean peak area } \pm \text { SD } \\
(\% R S D)\end{array}$} \\
\hline 20 & \multicolumn{2}{|c|}{$514096.67 \pm 636.41(0.13)$} & \multicolumn{2}{|c|}{$510790.67 \pm 3465.79(0.68)$} \\
\hline 50 & \multicolumn{2}{|c|}{$1350126.67 \pm 3515.91(0.26)$} & \multicolumn{2}{|c|}{$1345668.67 \pm 7369.41(0.55)$} \\
\hline 100 & \multicolumn{2}{|c|}{$2567327.00 \pm 2513.28(0.10)$} & \multicolumn{2}{|c|}{$2547848.00 \pm 16967.82(0.67)$} \\
\hline \multicolumn{5}{|c|}{ Accuracy } \\
\hline $\begin{array}{c}\text { Spiked conc. } \\
\mu \mathrm{g} / \mathrm{mL}\end{array}$ & $\begin{array}{c}\text { Total conc. } \\
\mu \mathrm{g} / \mathrm{mL}\end{array}$ & $\begin{array}{l}{ }^{*} \text { Mean peak area } \\
\pm \text { SD }(\% \text { RSD })\end{array}$ & $\begin{array}{c}\text { Drug found, } \\
\mu \mathrm{g} / \mathrm{mL}\end{array}$ & $\%$ Recovery \\
\hline $50(50 \%)$ & 150 & $3961402.33 \pm 36731.44(0.12)$ & 149.32 & 99.55 \\
\hline $100(100 \%)$ & 200 & $5299109.00 \pm 7685.98(0.15)$ & 199.76 & 99.88 \\
\hline $150(150 \%)$ & 250 & $6627715.67 \pm 42467.24(0.64)$ & 249.85 & 99.94 \\
\hline
\end{tabular}

$*$ Mean of three replicates

The robustness of an analytical procedure refers to its ability to remain unaffected by small and deliberate variations in method parameters and provides an indication of its reliability for routine analysis ${ }^{14}$. The results obtained (Table 4) from assay of the test solutions were not affected by varying the conditions and were in accordance with the results for original conditions. The \% RSD was less than $2.0 \%(0.53-1.22)$ indicating that the proposed method is robust.

Table 4. Robustness study of Cabazitaxel

\begin{tabular}{ccccc}
\hline Parameter & Condition & $\begin{array}{c}* \text { Mean } \\
\text { peak area }\end{array}$ & $\begin{array}{c}\text { *Mean peak area } \pm \text { SD } \\
(\% \text { RSD })\end{array}$ & $\begin{array}{c}* \text { Assay, } \\
\%\end{array}$ \\
\hline Flow rate & 0.9 & 2548571 & $2563665.67 \pm 13680.34$ & \\
$( \pm 0.1 \mathrm{~mL} / \mathrm{min})$ & 1.0 & 2567180 & $(0.53)$ & 99.86 \\
Detection & 1.1 & 2575246 & & \\
wavelength & 232 & 2569874 & $2559906.00 \pm 14992.64$ & 99.71 \\
$( \pm 2$ nm $)$ & 234 & 2567180 & $(0.59)$ & \\
Mobile phase & $28: 72$ & 2512335 & & \\
composition & $30: 70$ & 2567180 & $(1.08)$ & \\
$( \pm 2 \%, \mathrm{v} / \mathrm{v})$ & $32: 68$ & 2543641 & & \\
& 4.9 & 2524563 & $2559051.00 \pm 31227.39$ & 99.68 \\
$\mathrm{pH}$ & 5.0 & 2567180 & $(1.22)$ & \\
$( \pm 0.1$ unit $)$ & 5.1 & 2585410 & &
\end{tabular}

* Mean of three replicates

As the marketed formulation was not available the drug was mixed with different excipients available in the laboratory and then extracted using the mobile phase. The representative chromatogram of Cabazitaxel was shown in Figure 2A. The proposed method was applied to the laboratory prepared formulation and the percentage recovery was calculated as 98.57 .

\section{Forced degradation studies}

The stability indicating capability of the method was established from the separation of cabazitaxel peak from the degraded samples. Cabazitaxel has shown $33.17 \%$ degradation 
with two degradants at $1.472 \mathrm{~min}$ and 1.944 min during acidic stress indicating that the drug is more sensitive towards acidic environment. The amino group present in the drug structure may be highly responsible for this degradation. $22.15 \%$ of cabazitaxel has also undergone decomposition with a degradant at during oxidation indicating that the drug is sensitive towards oxidation. In other degradations the drug has undergone decomposition slightly $(<15.0 \%)$. Typical chromatograms obtained from the stressed samples were shown in Figure 2B-2F. A slight decomposition was seen on exposure of cabazitaxel solution to acidic (33.17\%), alkaline $(14.32 \%)$, oxidative $(22.15 \%)$ thermal $(14.50 \%)$ and photolytic $(6.74 \%)$ conditions (Table 5).

The present stability-indicating method for the determination of cabazitaxel in pharmaceutical formulations is specific because the drug peak was well separated even in the presence of degradation products. Also, the overall data demonstrated that the excipients and the degradation products did not interfere with the cabazitaxel peak. The system suitability parameters for the cabazitaxel peak shows that the theoretical plates were more than 2000 and the tailing factor was less than 2 (or $<1.5-2.0)$ (Table 5).

Table 5. Forced degradation studies of cabazitaxel

\begin{tabular}{cccccc}
\hline $\begin{array}{c}\text { Stress } \\
\text { Condition }\end{array}$ & $\begin{array}{c}* \text { Mean } \\
\text { peak area }\end{array}$ & $\begin{array}{c}\text { *Drug } \\
\text { recovered, \% }\end{array}$ & $\begin{array}{c}\text { *Drug } \\
\text { decomposed, \% }\end{array}$ & $\begin{array}{c}\text { Theoretical } \\
\text { plates }\end{array}$ & $\begin{array}{c}\text { Tailing } \\
\text { factor }\end{array}$ \\
\hline $\begin{array}{c}\text { Standard } \\
\text { (Untreated) }\end{array}$ & 2567180 & 100 & - & 5975 & 0 \\
Acidic & 1715519 & 66.83 & 33.17 & 7326 & 0 \\
Alkaline & 2199683 & 85.68 & 14.32 & 7389 & 1.436 \\
Oxidative & 1998488 & 77.85 & 22.15 & 7687 & 1.336 \\
Thermal & 2195016 & 85.50 & 14.50 & 7609 & 1.326 \\
Photolytic & 2394235 & 93.26 & 6.74 & 7377 & 1.319 \\
\hline
\end{tabular}

*Mean of three replicates

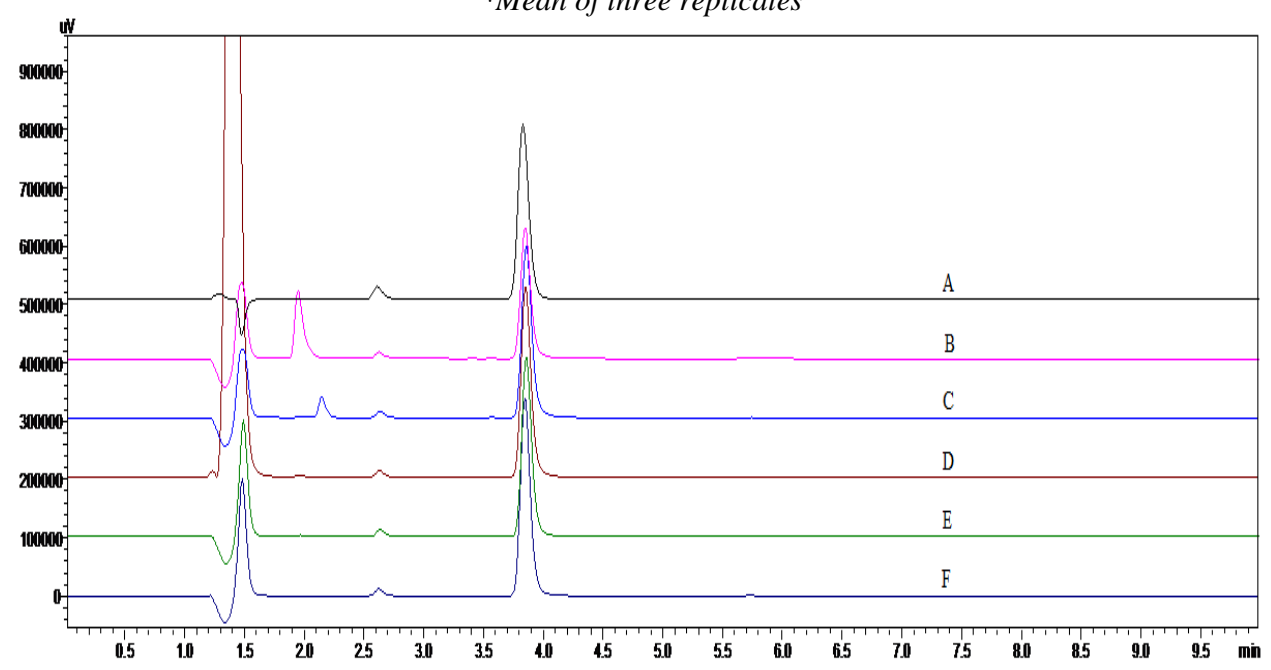

Figure 2. Typical chromatograms of Cabazitaxel $(100 \mu \mathrm{g} / \mathrm{mL})[\mathrm{A}]$, acidic [B], alkaline [C], oxidative [D], thermal [E] and photolytic [F] degradation 


\section{Conclusion}

The proposed stability-indicating HPLC method was validated as per ICH guidelines and applied for the determination of cabazitaxel in pharmaceutical dosage forms and can be successfully applied to perform long-term and accelerated stability studies of cabazitaxel formulations.

\section{Acknowledgement}

The authors are grateful to UGC, New Delhi for their financial support, M/s GITAM University for providing necessary research facilities and to Dr. Reddy's Labs (India) for providing the gift samples of Cabazitaxel.

\section{References}

1. O’Neil M J, The Merck Index, Merck Research Laboratories, Whitehouse Station, NJ, 2006.

2. Oudard S, TROPIC: Phase III trial of Cabazitaxel for the Treatment of Metastatic Castration-Resistant Prostate Cancer, Future Oncol., 2011, 7, 497-506.

3. Assessment Report for Jevtana (Cabazitaxel), Procedure No.: EMEA/H/C/002018, European Medicines Agency, London, 2011.

4. De Bono J S, Oudard S, Ozguroglu M, Hansen S, Machiels J P, Kocak I, Gravis G, Bodrogi I, Mackenzie M J, Shen L, Roessner M, Gupta S and Sartor A O, Lancet 2010, 376(2-8), 1147-1154.

5. Jevtana (cabazitaxel) Injection Approved by U.S. FDA After Priority Review" (Press release). sanofi-aventis. 2010-06-17. Retrieved June 17, 2010.

6. Cheetham P and Petrylak D P, Cancer J., 2013, 19(1), 59-65.

7. Pivot X, Koralewski P, Hidalgo J L, Chan A, Goncalves A, Schwartsmann G, Assadourian S and Lotz J P, Ann Oncol., 2008, 19(9), 1547-1552; DOI:10.1093/annonc/mdn171

8. Villanueva C, Awada A, Campone M, Machiels J P, Besse T, Magherini E, Dubin F, Semiond D and Pivot X, Eur J Can., 2011, 47(7), 1037-1045;

DOI:10.1016/j.ejca.2011.01.001

9. Gudisa Kishore, Int J Res Rev Pharm Appl Sci., 2012, 2(5), 950-958.

10. Mathrusri Annapurna M, Pramadvara K, Venkatesh B and Sowjanya G, Indo American J Pharm Res., 2013, 3(11), 9262-9269.

11. Kort A, Hillebrand M J, Cirkel G A, Voest E E, Schinkel A H, Rosing H, Schellens J H M and Beijnen J H, J Chromatogr. B, 2013, 925, 117-123.

12. Jagannath Patro V, Nageshwara Rao R and Tripathy N K, Open Access Scientific Reports, 2012, 1(6), 1-4.

13. Peter de Bruijn, Anne-Joy M de Graan, Annemieke Nieuweboer, Ron H J Mathijssen, Mei-Ho Lam, Ronald de Wit, Erik A C Wiemer and Walter J Loos, J Pharm Biomed Anal., 2012, 59, 117-122.

14. ICH Validation of analytical procedures: Text and methodology Q2 (R1), International Conference on Harmonization, 2005.

15. ICH Stability Testing of New Drug Substances and Products Q1A (R2), International Conference on Harmonization, 2003. 